\title{
INTERNET JAKO MEDIUM PAMIĘCI ZBIOROWEJ MLODYCH LUDZI. PRZYKLAD SIECIOWEJ AKTYWNOŚCI WOKÓŁ FILMU MIASTO 44
}

\section{DOI: $10.15290 /$ sp.2016.24.13}

Słowa kluczowe: Pamięć zbiorowa, Internet, Facebook, Miasto 44, Powstanie Warszawskie, film historyczny, film polski

Pamięć zbiorowa to w ujęciu Barbary Szackiej, ,,[zbiór] wyobrażeń członków zbiorowości o jej przeszłości, o zaludniających ją postaciach i minionych wydarzeniach, jakie w niej zaszły, a także sposobów ich upamiętniania i przekazywania o nich wiedzy uważanej za obowiązkowe wyposażenie członka tej zbiorowości. Inaczej mówiąc, [...] wszystkich świadomych odniesień do przeszłości, które występują w bieżącym życiu zbiorowym"1. Naukowa refleksja nad tym zjawiskiem ma długą tradycję, sięgającą lat 20. XX wieku i pionierskiej pracy socjologa Maurice’a Halbwachsa ${ }^{2}$. Współcześnie temat wciąż wzbudza zainteresowanie licznych badaczy, reprezentujących różne dyscypliny naukowe, m.in. socjologię, historię, czy psychologię społeczną.

Wydaje się, że jedną z ważnych przyczyn współczesnego zainteresowania tematem jest pluralizacja treści i form upamiętniania. Jak twierdzi Halbwachs, „społeczeństwo, zależnie od okoliczności i zależnie od czasu, rozmaicie przedstawia sobie przeszłość: zmienia bowiem swoje konwencje". ${ }^{3}$ Obecnie, podstawowym medium masowej komunikacji, a tym samym platformą służącą konstrukcji pamięci zbiorowej, staje się Internet. Wydaje się, że konwencje komunikacji w sieci w coraz większym stopniu decydują o tym, które wydarzenia $\mathrm{z}$ przeszłości są pamiętane oraz $\mathrm{w}$ jaki sposób są upamiętniane. Świadczy o tym m.in. postępujący proces cyfryzacji zasobów pamięci

\footnotetext{
B. Szacka, Czas przeszły, pamięć, mit, Warszawa 2006, s. 19.

M. Halbwachs, Społeczne ramy pamięci, Warszawa 1969.

3 Tamże, s. 407.
} 
(zbiorów muzealnych, bibliotek), czy wzrost zainteresowania naukowym badaniem fenomenów pamięci zbiorowej w Internecie ${ }^{4}$.

Można przypuszczać, że zjawisko cyfryzacji pamięci zbiorowej w największym stopniu dotyczy młodych pokoleń, dla których obecność i aktywność w Internecie wydaje się nie tylko oczywistością, ale wręcz obowiązkiem. Dlatego też interesujące może być przedstawienie sieciowej aktywności wokół współczesnego filmu historycznego, który w założeniu miał być skierowany przede wszystkim do młodzieży. Chodzi o Miasto 44 (2014), w reżyserii Jana Komasy, film opowiadający o losach młodych ludzi w czasie okupacji i Powstania Warszawskiego.

Celem poniższego artykułu jest przede wszystkim jakościowa analiza wpisów dotyczących filmu Miasto 44 na portalu społecznościowym Facebook. Z pewnością jest to obecnie jeden z głównych węzłów wymiany informacji w Internecie. Daje zarówno możliwość prostego przekazywania treści od administratorów do odbiorów, jak i włączania się do dyskursu samych użytkowników ${ }^{5}$. W poniższym artykule autor przygląda się treściom oficjalnych przekazów (pochodzących od producentów filmu), alternatywnym wobec nich treściom fanowskim oraz dyskusjom i komentarzom użytkowników, zarówno na profilach oficjalnych, jak i nieoficjalnych.

Specyfika analizowanych danych internetowych nie pozwala na precyzyjne ustalenie cech socjodemograficznych użytkowników (takich jak wiek lub płeć), autor nie jest więc w stanie precyzyjnie ustalić, w jaki sposób odbiór filmu różnił się wśród poszczególnych grup widzów. Nie sposób również, bez podjęcia badań $\mathrm{z}$ wykorzystaniem metod reaktywnych, ustalić, w jaki sposób film Miasto 44 faktycznie wpłynął na pamięć zbiorową o Powstaniu Warszawskim. Analiza danych zastanych pozwala jednak ustalić, jakie wątki czy konwencje organizowały dyskurs wokół filmu. Wydaje się to istotne, ponieważ Powstanie Warszawskie jest - używając terminologii Pierre'a Nora - jednym z najważniejszych polskich „miejsc pamięci”, czyli punktów odniesienia, wokół których krystalizuje się tożsamość zbiorowa społeczności ${ }^{6}$. Natomiast dyskurs dotyczący tego wydarzenia, jednym z newralgicznych elementów współczesnej polskiej polityki pamięci. Wydaje się, że niniejszy

4 Dobrym przykładem zainteresowań polskich badaczy jest zbiór: Sieć pamięci. Cyfrowe postaci pamięci społecznej, red. A. Fiń, Ł. Kapralska, Kraków 2015.

5 Jest to element tzw. Web 2.0, czyli sieci opartej na treściach generowanych przez użytkowników.

6 C. Carnecac-Lecomte, Podobieństwa i różnice między francuskimi "Lieux de memoires" i niemieckimi „Erinnerungsorte”, [w:] Deutsch-polnische Erinnerungsorte. Polsko-niemieckie miejsca pamięci, red. K. Jabłonowski, K. Kończal, M. Matlak, Berlin 2009. 
artykuł może stanowić też pewien przyczynek do historii pamięci powstania warszawskiego. Najnowsze, kompleksowe opracowanie tego tematu, autorstwa Marcina Napiórkowskiego ${ }^{7}$, nie obejmuje bowiem kwestii związanych z filmem Miasto 44.

W 2005 r. Ministerstwo Kultury i Dziedzictwa Narodowego oraz Polski Instytut Sztuki Filmowej ogłosiły konkurs na scenariusz filmu fabularnego oraz dokumentalnego poświęconego powstaniu warszawskiemu. Wpłynęły nań 62 scenariusze fabuł i 15 dokumentów ${ }^{8}$. Andrzej Wajda, reżyser legendarnego Kanału (1956), był wobec konkursu sceptyczny, nie widząc wśród widowni, szczególnie młodej, realnego zainteresowania tematem ${ }^{9}$. Diagnoza ta okazała się jednak w dłuższej perspektywie błędna. Co prawda, jeszcze w 2010 r. Barbara Hollender opisywała bezowocne próby realizacji projektów, które znalazły uznanie konkursowego jury - dotyczyły one przede wszystkim trudności w zdobyciu funduszy oraz braku wyraźnej woli politycznej nakręcenia takiego obrazu ${ }^{10}$ - ale $\mathrm{w}$ ciągu następnych lat sytuacja znacznie się zmieniła. Co ciekawe, najnowsze obrazy poświęcone Powstaniu zostały nakręcone przez młodych twórców, bądź wyraźnie skierowane do młodej publiczności. Jan Komasa wyreżyserował Miasto 44 (2014) oraz był pomysłodawcą fabularyzowanego dokumentu Powstanie Warszawskie (2014), wyprodukowanego przez Muzeum Powstania Warszawskiego. Rok wcześniej weszły na ekrany filmy Sierpniowe niebo. 63 dni chwały (2013), w reżyserii Ireneusza Dobrowolskiego oraz Był sobie dzieciak (2013), w reżyserii Leszka Wosiewicza. Nakręcono również specjalny, poświęcony powstaniu warszawskiemu sezon popularnego serialu telewizyjnego Czas honoru. Powstanie (2014).

$\mathrm{Na}$ tym tle Miasto 44 zajmuje wyjątkową pozycję. Jest to jeden z najdroższych filmów w historii polskiej kinematografii ${ }^{11}$, wyreżyserowany przez Jana Komasę (ur. 1981), uważanego za jednego z wyróżniających się polskich filmowców młodego pokolenia. Rozmach realizacyjny oraz odżegnywanie się reżysera od inspiracji Kanałem ${ }^{12}$ sugerowały, że może to być dzieło będące

7 M. Napiórkowski, Powstanie umarlych. Historia pamięci 1944-2014, Warszawa 2016.

8 M. Hendrykowska, Film polski wobec wojny i okupacji. Tematy, motywy, pytania, Poznań 2011, s. 209.

9 M. Gil, Temat na dziś: film o powstaniu, „Kino” 2006, nr 9.

10 B. Hollender, Nikt już nie chce filmu o Powstaniu Warszawskim, „Rzeczpospolita” 2010, 27 lipca.

11 Koszt filmu wyniósł ok. 25 mln zł. Obraz został wyprodukowany przez Michała Kwiecińskiego, będącego współcześnie jedną z najważniejszych postaci decydujących o charakterze polskiego kina historycznego. Kwieciński był producentem takich filmów jak Katyń (2007), Joanna (2010), Wałęsa. Człowiek z nadziei (2013) oraz serialu Czas honoru (2008-2013).

12 J. Wróblewski, I rozpętało się piekło..., „Polityka” 2014, nr 30. 
nowym „punktem orientacyjnym” dla pamięci zbiorowej Powstania. Szczególnie dla młodych pokoleń, dla których obrazy powstałe wcześniej mogą być $\mathrm{w}$ dużej mierze nieatrakcyjne lub niezrozumiałe. Warto więc pochylić się nad tym, w jaki sposób Miasto 44 zostało odebrane przez młode pokolenie widzów, a ściślej, jaki ślad film pozostawił po sobie w Internecie.

Miasto 44, zgodnie z oczekiwaniami, okazało się jednym z największych hitów współczesnej polskiej kinematografii. W ciągu roku od premiery, czyli 19 września 2014 r., film obejrzało w kinach 1750000 widzów. Jest to trzecia pod względem liczby widzów polska produkcja od 2010 do połowy 2015 r. ${ }^{13}$ Trudno jest dodatkowo oszacować liczbę widzów, którzy mieli okazję zetknąć się z filmem w Internecie lub na nośnikach DVD i Blu-Ray. Z pewnością można jednak stwierdzić, że film odbił się szerokim echem wśród polskich odbiorców, co pokazuje również aktywność internetowa wokół obrazu.

Jako miarę owej aktywności możemy potraktować nie tylko wpisy na portalu społecznościowym Facebook, ale również na popularnym polskim portalu filmowym filmweb.pl. W tym celu porównano wyniki Miasta 44 oraz innych popularnych produkcji ostatnich lat, filmów Bogowie oraz Jack Strong (odpowiednio pierwszy i trzeci polski film pod względem liczby widzów w 2014 r.), a także Jesteś Bogiem (polski film z największą frekwencją w 2012 r., również skierowany przede wszystkim do młodszych odbiorców). W tabeli 1 przedstawiono liczbę użytkowników portalu filmweb.pl, którzy ocenili, a więc - jak można przypuszczać - obejrzeli poniższe obrazy, wraz ze średnią oceną (w skali od 1 do 10) oraz liczbą wątków na forach poświęconych każdemu z tytułów.

Tabela 1. Aktywność na portalu filmweb.pl wokół wybranych filmów polskicha

\begin{tabular}{|l|c|c|c|}
\hline Tytuł & $\begin{array}{c}\text { Liczba } \\
\text { oddanych } \\
\text { głosów }\end{array}$ & $\begin{array}{c}\text { Średnia } \\
\text { ocena }\end{array}$ & $\begin{array}{c}\text { Liczba } \\
\text { wątków } \\
\text { na forum }\end{array}$ \\
\hline Miasto 44 & 93807 & 6,7 & 1365 \\
Bogowie & 159440 & 8,2 & 475 \\
Jack Strong & 86285 & 7,5 & 560 \\
Jesteś Bogiem & 148357 & 6,8 & 1673 \\
\hline
\end{tabular}

a) stan na $15.10 .2015 \mathrm{r}$.

Źródło: opracowanie własne.

13 https://www.pisf.pl/rynek-filmowy/box-office/filmy-polskie [15.10.2015]. 
Tabela pokazuje, że w opinii użytkowników portalu filmweb.pl, Miasto 44 nie wyróżnia się na tle innych głośnych produkcji polskiej kinematografii, zarówno jeśli chodzi o liczbę ocen, jak i uśredniony wynik. Warto jednak zwrócić uwagę, że Miasto 44, podobnie jak Jesteś Bogiem - filmy skierowane do młodszej publiczności - wygenerowały największą liczbę wątków na forach, co może sugerować, że wywołały one w odbiorcach największy odzew, wzbudziły emocje, zachęciły do refleksji.

Istotniejsze mogą być jednak statystki dotyczące portalu Facebook, o którym z większą pewnością można powiedzieć, że jest użytkowany w dużej mierze przez ludzi młodych (w 2014 r. 49\% polskich użytkowników miało nie więcej niż 25 lat) ${ }^{14}$.

Tabela 2. Aktywność na portalu Facebook wokół wybranych filmów polskich

\begin{tabular}{|l|c|c|}
\hline Tytuł & $\begin{array}{c}\text { Liczba fanów } \\
\text { na najpopularniejszej } \\
\text { stronie }\end{array}$ & $\begin{array}{c}\text { Liczba stron } \\
\text { z ponad 1 tys. } \\
\text { fanów }\end{array}$ \\
\hline Miasto 44 & 202740 & 18 \\
Bogowie & 58830 & 2 \\
Jack Strong & 7712 & 2 \\
Jesteś Bogiem & 496981 & 7 \\
\hline
\end{tabular}

Źródło: opracowanie własne.

Tabela 2 pokazuje, że filmem, który zebrał największą liczbę fanów na jednym profilu było Jesteś Bogiem (blisko pół miliona polubień). W przypadku Miasta 44, najpopularniejsza strona zgromadziła również niebagatelną liczbę ponad 200 tys. fanów. Co ciekawe, na temat tego filmu powstało również szereg stron nieoficjalnych, prowadzonych przez fanów. Aż osiemnaście z nich zdołało zebrać ponad tysiąc użytkowników. Sugeruje to, że odbiorcy filmu odczuwali dość silną, wewnętrzną potrzebę wymiany informacji i opinii na temat tego obrazu ${ }^{15}$.

\footnotetext{
14 A. Prejs, Facebook w Polsce - podsumowanie 2014 r., http://blog.sotrender.com/pl/2015/02/ facebook-polska-2014 [15.10.2015].

15 Nie jest w tym miejscu istotne, że niektóre $\mathrm{z}$ tych stron zostały następnie skomercjalizowane np. jako platformy sprzedaży odzieży i gadżetów patriotycznych. Być może były nawet zakładane $\mathrm{z}$ taką intencją, jednak $\mathrm{w}$ okresie kiedy zainteresowanie filmem było największe, publikowały treści bezpośrednio z nim związane i generowały aktywność użytkowników właśnie na ten temat.
} 
Cząstkowe informacje, jakie udało się uzyskać od administratorów profili poświęconych Miastu $44^{16}$ pozwalają przypuszczać, że film ten rzeczywiście zainteresował przede wszystkim najmłodszych odbiorców. Dostępne dane pokazują, że $96 \%$ fanów to osoby przed 25 rokiem życia, a $64 \%$ nie osiągnęło jeszcze pełnoletności. Ponadto, dwie trzecie użytkowników to kobiety. Taki rozkład demograficzny pokrywa się także ze statystykami międzynarodowego portalu filmowego imdb.com, pokazującymi, że Miasto 44 najwyżej oceniały internautki w wieku poniżej 18 lat ${ }^{17}$.

Można założyć, że Internet stał się dla młodych ludzi istotnym medium wymiany informacji i opinii na temat filmu Miasto 44, a tym samym, pośrednio, również na temat Powstania Warszawskiego. Jednocześnie należy zwrócić uwagę, że portale społecznościowe (w tym wypadku Facebook) wyraźnie preferują określone formy przekazu. Chodzi tu przede wszystkim o wypowiedzi zwięzłe, nacechowane emocjonalnie, często połączone $\mathrm{z}$ materiałem wizualnym. Kryterium słuszności opinii jest powiązane ze społecznym uznaniem (np. w postaci liczby kliknięć „lubię to"), co sprawia, że preferowane są z jednej strony wypowiedzi błyskotliwe ${ }^{18}$, z drugiej zaś zrozumiałe dla jak najszerszej grupy odbiorców, a więc niekontrowersyjne i nieskomplikowane. Poniżej zostanie zaprezentowana jakościowa analiza pięciu najpopularniejszych stron na portalu Facebook poświęconych filmowi Miasto $44^{19}$. Analizowano przede wszystkim treści zamieszczane od 15 września 2014 r. (na 4 dni przed premierą filmu) do marca 2015 r., kiedy - według statystyk firmy Google 20 - zakończył się w Internecie etap największego zainteresowania produkcją. $\mathrm{W}$ trakcie analizy zwracano uwagę przede wszystkim

16 O udostępnienie informacji dotyczących demografii fanów zostali poproszeni administratorzy 18 największych fanpage'y filmu Miasto 44. Na prośbę odpowiedziało zaledwie dwóch $\mathrm{z}$ nich, profile te należą jednak do największych (łącznie blisko 100 tys. fanów w dniu 15.10.2015), co pozwala ostrożnie założyć, że odpowiada to ogólnej strukturze demograficznej fanów filmu na portalu Facebook.

17 http://www.imdb.com/title/tt3765326/ratings?ref_=tt_ov_rt [15.10.2015].

18 Bardzo popularna stała się np. wypowiedź internauty, który na prośbę o krótkie scharakteryzowanie Biedronki, jednej z bohaterek filmu, napisał: „,codziennie niskie ceny, produkty polskie", por. http://mistrzowie.org/613000 [15.10.2015].

19 Nie zdecydowano się na analizę ilościową, ponieważ specyfika języka używanego na portalu Facebook przez najmłodszych użytkowników - duża liczba skrótów, błędów ortograficznych, anglicyzmów i emotikon - sprawia, że rzetelna ilościowa analiza danych opartych na wyszukiwaniu częstotliwości występowania wyrażeń kluczowych jest bardzo trudna. $\mathrm{Z}$ pewnością, podjęcie tego rodzaju trudu byłoby zasadne np. przy poszerzonej analizie aktywności młodych ludzi w Internecie w kontekście przeszłości i pamięci.

20 https://www.google.pl/trends/explore\#q=miasto\%2044 [15.10.2015]. 
na sposoby, w jakie treści umieszczane przez administratorów i zwykłych użytkowników (fanów) odnosiły się do Powstania Warszawskiego oraz pamięci o nim.

Największą liczbę fanów, ponad 200 tysięcy, zgromadził oficjalny profil filmu, który charakteryzował się wyraźnie odmienną od pozostałych formą. Publikowane tam informacje (posty) w znacznej mierze dotyczyły samego filmu, jego powstawania, recenzji, pokazów zagranicznych, otrzymywanych nagród. Zamieszczano tam również oficjalne materiały okołofilmowe - fotosy, wywiady $\mathrm{z}$ aktorami, klipy making of. Pojawiały się one szczególnie często $\mathrm{w}$ pierwszym okresie po premierze. Tym samym, zawarte na tej stronie treści składały się raczej na opowieść o samym filmie (jako produkcji), a nie jego fabule. Administratorzy profilu zadbali jednak również o nawiązania do wydarzeń historycznych, tworząc dwie kategorie postów oznaczone hashtagami (znacznikami) \#kartka44 oraz \#wyzwanie44.

Pierwszy z nich (\#kartka44) stanowił rodzaj kalendarium, nie tylko Powstania Warszawskiego, ale również całego okresu okupacji. Posty publikowane w sierpniu i wrześniu 2014 r. odnosiły się do wydarzeń, które miały miejsce tego samego dnia w okresie wojny. Najczęściej łączyły zwięzłą notatkę historyczną z materiałem wizualnym - krótkim filmem, zdjęciem archiwalnym lub fotosem $\mathrm{z}$ filmu Miasto 44 (te cieszyły się zazwyczaj największą popularnością, mierzoną liczbą reakcji „lubię to"). Zwięzła forma "kartki z kalendarza” sugerowała neutralność przekazu, jednak w warstwie tekstowej wyraźnie pojawiały się elementy emocjonalizujące treść, np. zwroty: „Pamiętamy!", „Chwała bohaterom" lub internetowy symbol znicza - [*]. W pojedynczych przypadkach próbowano również zaangażować użytkowników do interakcji, stawiając pytania dotyczące współczesnego upamiętniania przeszłości (np. "Czy wiecie coś na temat tej akcji?”, „Wiecie gdzie znajduje się ta tablica?"). Sądząc po liczbie komentarzy - najpopularniejsze posty tego typu zebrały ich ponad 60 - zakończyło się to sukcesem.

Innego rodzaju aktywność fanów wiązała się z kategorią \#wyzwanie44. Był to $\mathrm{w}$ istocie rodzaj internetowego konkursu, w którym można było wygrać gadżety związane z filmem Miasto 44. Posty z tej kategorii zazwyczaj zawierały pytania dotyczące samego filmu (fabuły, postaci), niektóre z odsłon konkursu dotyczyły jednak również powstania warszawskiego. Pytania te, nie licząc wyjątków (np. „Ile dni trwało Powstanie Warszawskie?”), wymagały pewnego poziomu wiedzy historycznej i stanowiły rzeczywiste forum wymiany informacji na temat przeszłości. Pytano więc m.in. o to, co wydarzyło się konkretnego dnia Powstania, jakiego typu czołgi udało się przejąć 
powstańcom w określonym czasie lub jak nazywała się powstańcza gazetka wydawana z myślą o dzieciach. Tego rodzaju pytania nie generowały znacząco mniejszej liczby odpowiedzi od innych zadań konkursowych, co sugeruje, że historyczne fakty okazały się wcześniej znane lub interesujące dla istotnej grupy fanów tego profilu.

Charakterystyczne były również zadania wymagające ogólniejszej refleksji i aktywności odbiorców. Mieli oni np. napisać „dlaczego dla Ciebie ważna jest pamięć o tamtych dniach" lub opowiedzieć o „uczuciu, które towarzyszyło mi po obejrzeniu Miasta 44". Warto zwrócić uwagę, że administratorzy profilu premiowali $w$ tych przypadkach wypowiedzi długie (jak na standardy portalu społecznościowego), co sprawiało, że ich poziom był stosunkowo wysoki, z pewnością zdecydowanie wyższy niż na omawianych w dalszej części tekstu stronach nieoficjalnych. $Z$ drugiej strony, trudno jest ocenić, na ile uczestnicy konkursu pisali to, co rzeczywiście przeżywali. Być może były to po prostu wypowiedzi, które - jak oczekiwali piszący - będą wysoko oceniane przez organizatorów.

Warto zwrócić wreszcie uwagę na fakt, że niektóre z zadań publikowanych w ramach \#wyzwania44 skłaniały użytkowników do zanurzenia się (immersji) w świat przedstawiony. Można to porównać do (wirtualnej) rekonstrukcji historycznej, czyli próby wyobrażenia siebie w przeszłej rzeczywistości. Pytano więc internautów np. o to, w jakiego bohatera chcieliby się wcielić lub jaki wybraliby sobie pseudonim konspiracyjny. Drugi z przykładów jest ciekawy, ponieważ w wielu wypowiedziach użytkowników odnaleźć można wizję powstania jako przygody, w istocie sprzeczną z wydźwiękiem filmu. Obrazują to przykładowe wpisy: "Jesionka - bo szyłbym najlepsze jesionki szkopom - drewniane $2 \mathrm{~m}$ na $50 \mathrm{~cm}$,, „Lupka, bo łupałabym głowy Niemcom”, „Widmo - pojawiałbym się znienacka i siał panikę pośród wrogich oddziałów okupanta, przez co sami Niemcy baliby się tego pseudonimu". Z drugiej strony, zadanie to wywołało również pojedyncze reakcje krytyczne, oskarżenie administratorów profilu i biorących udział w konkursie internautów o trywializację historii dla celów komercyjnych (np. „Według mnie taka zabawa to brak szacunku dla żołnierzy [...] Robicie sobie z tragedii jakiś festyn"). Wyobrażenia o Powstaniu jako przygodzie pojawiły się licznie również $\mathrm{w}$ przypadku konkursu polegającego na wklejeniu w komentarzu pod postem niebanalnego zdjęcia $z$ biletami na film Miasto 44. W odpowiedzi pojawiły się m.in. zdjęcia biletów nadpalonych, ułożonych obok polskich flag, atrap broni, elementów umundurowania, symboli Polski Walczącej. Trudno oprzeć się wrażeniu, że tego rodzaju działania, służące immersji, czyli zanurzeniu odbiorców w świecie przedstawionym 
w filmie ${ }^{21}$, jednocześnie zakorzeniają Powstanie w pamięci zbiorowej młodego pokolenia i tworzą z samego wydarzenia rodzaj symulakrum. Przestaje ono być osadzone $\mathrm{w}$ konkretnym kontekście historycznym czy politycznym.

Profile nieoficjalne prowadzili przede wszystkim fani, którzy w ten sposób wyrażali naturalną potrzebę wymiany opinii na temat filmu, który zrobił na nich wrażenie. $Z$ zamieszczanych przez administratorów informacji wywnioskować można, że przynajmniej część stron prowadzona była przez użytkowników w wieku szkolnym, a więc przedstawicieli najliczniejszej grupy widzów-internautów. Ma to oczywiście swoje konsekwencje. Administratorzy nie chcąc, bądź nie mając odpowiednich kompetencji, niemal zupełnie nie odnosili się do konkretnego, historycznego kontekstu fabuły. W związku z tym, treści występujące na tych profilach można uznać za daleko mniej związane $\mathrm{z}$ faktami historycznymi, czy szeroko rozumianą pamięcią zbiorową, niż na oficjalnym profilu filmu. W przypadku stron nieoficjalnych dominowały posty zawierające fotosy $\mathrm{z}$ filmu połączone niekiedy z krótkimi dopiskami. W warstwie tekstowej były to najczęściej cytaty z filmu lub autorskie komentarze dotyczące zawartości zdjęcia. Te ostatnie dotyczyły głównie sympatii i antypatii administratorów wobec postaci występujących w filmie lub aktorów odtwarzających ich role. Zarówno treści postów, jak i komentarze użytkowników w istotnej mierze okazywały się próbami wykazania wyższości jednej z dwóch głównych bohaterek kobiecych. Wydaje się więc, że określone zabiegi twórców filmu, mające na celu uwspółcześnienie przekazu, takie jak seksualizacja bohaterów, sprawiły, że obraz rzeczywiście stał się bliższy odbiorcom, ale oddalił się przy tym jego kontekst historyczny. Kiedy zarówno administratorzy, jak i fani na stronach nieoficjalnych nie mieli odpowiednich kompetencji lub ochoty do podjęcia rozmowy na temat faktów, dyskusje przenosiły się przede wszystkim na poziom moralnych ocen bohaterów trwających w miłosnym trójkącie, ewentualnie komentarzy na temat ich wyglądu.

Wśród postów, które odwoływały się do historycznej warstwy filmu, dominował przekaz nastawiony na emocje, perspektywę indywidualną oraz - co charakterystyczne - powiązanie ze współczesnością. Aktywność pod takimi postami stawała się więc swego rodzaju (wirtualną) rekonstrukcją historyczną. Dla przykładu, internauci odpowiadali na pytania administratora:

21 Skłania do tego również sam film, np. przez wykorzystanie tzw. ujęć POV, czyli z punktu widzenia bohatera. 
„Czy weszlibyście do kanału by przejść na spokojną część Warszawy, czy wolelibyście zostać i być skazani na pewną śmierć?”; „Pytanie, na które pragnę SZCZEREJ [zaznaczenie administratora strony] odpowiedzi. Gdybyście mieli wybór, czy walczylibyście w Powstaniu?". Podejmowane próby pogłębionej refleksji na temat Powstania, np. pytania w rodzaju "Co waszym zdaniem było przyczyną przegrania Powstania?" spotykały się z o wiele mniejszym odzewem odbiorców niż inne wpisy, a odpowiedzi były zazwyczaj podobnie zwięzłe jak samo pytanie.

Porównanie oficjalnej strony filmu oraz profilów nieoficjalnych prowadzi do pewnych ogólnych wniosków na temat treści poświęconych Miastu 44 na portalu Facebook. Odpowiednio moderowana strona oficjalna w zdecydowanie bardziej widoczny sposób nawiązywała do historycznego kontekstu filmu, a umieszczane treści prowadziły w dwóch kierunkach. Z jednej strony, do stosunkowo rzetelnej dyskusji o historii z elementami edukacji patriotycznej (przede wszystkim kategoria \#kartka44). Z drugiej, do zanurzania odbiorców w świecie przedstawionym, co skutkowało emocjonalizacją aktywności użytkowników, ale również anachronizmem przekazu, którego wyrazistym przykładem może być zdjęcie nadpalonych biletów do Multikina ułożonych obok "kotwicy” Polski Walczącej. Brak chęci lub kompetencji moderatorów stron nieoficjalnych prowadził natomiast do nieco innego odbioru filmu na tych profilach. Został on z jednej strony przedstawiony jako młodzieżowy romans „na tle epoki”, z drugiej natomiast jako impuls do zindywidualizowanego, emocjonalnego przekazu (co ja zrobiłbym na ich miejscu?) oraz wymiany treści patriotycznych, wyabstrahowanych z konkretnego kontekstu historycznego i posługujących się ogólnymi pojęciami wojny, honoru, odwagi, obowiązku.

Miasto 44 jest wyraźnym przykładem tego, jak nowe historyczne produkcje filmowe przez swą treść i formę starają się trafić do najmłodszych grup odbiorców. Dzieje się to przede wszystkim za pomocą charakterystycznej konwencji emocjonalizacji Powstania oraz dzięki próbom jak najpełniejszego zanurzenia widzów w świecie przedstawionym (zamiast postawienia ich $\mathrm{w}$ roli zdystansowanych obserwatorów). Immersja zdaje się być nadrzędnym narzędziem współczesnych filmowców zwracających się do młodych widzów, chociaż prowadzić mogą do niej różne drogi. Reżyser Tomasz Bagiński na temat swojego nieukończonego projektu o Powstaniu Warszawskim pod tytułem Hardkor 44 powiedział: „Ten film będzie tak naprawdę bardziej o powstaniu mitologicznym niż prawdziwym. [...] Mnie się marzy film historyczny, który będzie tak naprawdę historię trochę olewał, film nowoczesny i efektowny. Bo kogo dziś interesuje chorobliwe trzyma- 
nie się faktów? [...] W kinie mamy budować emocje" 22. Jan Komasa próbował stworzyć film silnie zanurzony w realiach historycznych. Mówił: „Kluczem okazała się maksymalna wierność emocjom [...] Dla wszystkich przygotowaliśmy księgę postaci, żeby wiedzieli, kogo grają do kilku pokoleń wstecz. Wchodząc na plan, byliśmy perfekcyjnie przygotowani, aż czuło się szarpnięcie energii" ${ }^{23}$. Z perspektywy treści dostępnych na portalu Facebook, tego rodzaju przygotowanie okazało się jednak w dużej mierze bez znaczenia. Emocjonalizacja Powstania być może przywiązała je mocniej do rdzenia pamięci zbiorowej młodych Polaków, ominęła jednak istotne pytania na temat jego rzeczywistego sensu i znaczenia dla historii Polski, które podejmowały wcześniejsze teksty kultury, z ikonicznym Kanałem Andrzeja Wajdy na czele.

\title{
The Internet as a medium of young people's collective memory. The examples of Internet activity regarding the film Miasto 44
}

\begin{abstract}
Since the Internet is currently a vital medium of exchanging information and opinion about the past for young people, it can be said that the web significantly develops collective memory. The article presents characteristic forms and threads of the Internet communication concerning the film Miasto 44 (Warsaw 44) (2014) directed by Jan Komasa. Miasto 44 is one of the greatest Polish film productions of recent years and the film is mainly addressed at younger audience, which is potentially a new point of reference for them to commemorate the Warsaw Uprising.

The article focuses on a general presentation of the Internet users' activity connected with the film and attempts to describe in detail the demography of those interested in the film while carrying out a more profound analysis of the websites devoted to this production on Facebook. The article draws attention to the consequences of typical forms of communication in social media with regard to the shape of collective memory. It compares official and unofficial profiles of the film indicating an essential role of the competence and intentions of websites administrators for the nature of this communication. Moreover, the article quotes the most important and characteristic threads of the Internet communication about Miasto 44.
\end{abstract}

Key words: collective memory, the Internet, Facebook, Miasto 44 (Warsaw 44), Warsaw Uprising, historical film, Polish film

22 K. Pasternak, Odebrać prawicy flagę i orła, „Film” 2009, nr 8, s. 49.

23 J. Wróblewski, dz. cyt., s. 83-85. 


\section{Интернет как средство передачи информации о общенародной памяти Аля молодых людей. Пример сетевой активности, касающейся фильма Город 44}

\section{Абстракт}

Сегодня интернет для молодых людей является средством для обмена информацией и для высказывания на тему прошедших событий. На основании этого можем утверждать, что мировая сеть должным образом формирует общенародную память. Аанная статья указывает на характер и формы интернет-коммуникации, касающихся фильма Город 44 (2014), режиссером которого является Ян Комаса. Город 44 - одна из наиболее значимых польских кинопродукций последних лет. Фильм адресован, прежде всего, молодым зрителям и представляет собой новую точку отсчета в воспоминаниях о варшавском восстании.

В статье говорится об активности пользователей интернетом, касающейся фильма. Автор пробует определить демографию пользователей, заинтересованных фильмом, и более точно анализирует сайты, посвященные этой кинопродукции, на Facebook. Автор также обращает внимание на то, как влияют типичные формы общения на сайтах на формирование общенародной памяти. Он сравнивает официальные и неофициальные профили о фильме, указывая на важную роль компетенции и намерений администраторов сайтов в формировании характера информации. В статье указаны самые важные и наиболее характерные черты интернет-коммуникации на тему Город 44.

Ключевые слова: общенародная память, Интернет, Facebook, Город 44, Варшавское восстание, исторический фильм, польский фрильм

\section{Filmografia}

Miasto 44, reż. Jan Komasa, produkcja polska (Michał Kwieciński, Akson Studio), 2014

\section{Bibliografia}

\section{Książki i artykuły}

C. Carnecac-Lecomte, Podobieństwa i różnice między francuskimi "Lieux de memoires" i niemieckimi "Erinnerungsorte”, [w:] Deutsch-polnische Erinnerungsorte. Polsko-niemieckie miejsca pamięci, red. K. Jabłonowski, K. Kończal, M. Matlak, Berlin 2009.

M. Gil, Temat na dziś: film o powstaniu, „Kino” 2006, nr 9.

M. Halbwachs, Społeczne ramy pamięci, Warszawa 1969. 
M. Hendrykowska, Film polski wobec wojny i okupacji. Tematy, motywy, pytania, Poznań 2011.

B. Hollender, Nikt już nie chce filmu o Powstaniu Warszawskim, „Rzeczpospolita” 2010, 27 lipca.

M. Napiórkowski, Powstanie umartych. Historia pamięci 1944-2014, Warszawa 2016.

K. Pasternak, Odebrać prawicy flage i orła, „Film” 2009, nr 8.

Sieć pamięci. Cyfrowe postaci pamięci społecznej, red. A. Fiń, Ł. Kapralska, Kraków 2015.

B. Szacka, Czas przeszły, pamięć, mit, Warszawa 2006.

J. Wróblewski, I rozpętało się piekło..., „Polityka” 2014, nr 30.

\section{Strony Internetowe [15.10.2015]}

A. Prejs, Facebook w Polsce - podsumowanie 2014 r., www.blog.sotrender.com/pl/ 2015/02/facebook-polska-2014

Miasto 44, www.facebook.com/Miasto44/?ref=br_rs

Miasto 44, www.facebook.com/Miasto-44-295046247366652/?ref=br_rs

Miasto 44, www.facebook.com/Miasto-44-527751974036492/?ref=br_rs

Miasto 44, www.facebook.com/Miasto-44-1501032310176290/?ref=br_rs

Miasto 44, www.facebook.com/Miasto-44-281550508708748/?ref=br_rs

Miasto 44, www.imdb.com/title/tt3765326/ratings?ref_=tt_ov_rt

www.google.pl/trends /

www.pisf.pl/rynek-filmowy/box-office/filmy-polskie

Maciej Białous, doktor, pracuje w Instytucie Socjologii Uniwersytetu w Białymstoku.

e-mail: m.bialous@uwb.edu.pl

Piotr Gliński, prof. dr hab., socjolog, pracuje w Instytucie Socjologii Uniwersytetu w Białymstoku.

e-mail: pglinski@ifispan.waw.pl 